Annals of Plant and Soil Research 22(4): 386-389(2020)

https://doi.org/10.47815/apsr.2020.10009

\title{
Effect of foliar application of zinc and boron on growth and yield of cauliflower (Brassica oleracea var.bortrytis $L$.)
}

\author{
AMAN AGNIHOTRI, BRIJESH KUMAR, VISHWANATH, TEEKESH KUMAR AND DEEPAK \\ KARAN
}

Department of Horticulture, Raja Balwant Singh College, Bichpuri, Agra (U.P)-283105

Received: July, 2020; Revised accepted: September, 2020

\begin{abstract}
ABSTRUCT
The field experiment was carried out during rabi season of 2018-2019 at Research farm, Raja Balwant Singh College, Bichpuri Agra,(U.P) to study the effect of different concentrations of zinc and boron as foliar spray on the vegetative growth and yield of cauliflower (Brassica oleracea var.bortrytis). Nine treatments with three replications were evaluated in randomized block design. The results revealed that the maximum plant height $(44.90 \mathrm{~cm})$, diameter of stem $(1.68 \mathrm{~cm})$, length $(38.90 \mathrm{~cm})$ and width $(24.55 \mathrm{~cm})$ of longest leaf were recorded with the foliar spray of $0.50 \% \mathrm{Zn}+0.2 \%$ boron solution. The maximum values of spread of plant along the row $(53.51 \mathrm{~cm})$ and across the row $(55.25 \mathrm{~cm})$ and fully opened leaves per plant (12.94) were recorded with the foliar spray of $0.25 \% \mathrm{Zn}+0.2 \%$ boron solution. The yield of cauliflower curd was recorded maximum $\left(343.46 \mathrm{q} \mathrm{ha}^{-1}\right.$ ) with foliar application of $\mathrm{Zn}(0.50 \%)+$ boron $(0.2 \%)$. The increase in yield with this treatment was $23.9 \%$ higher than obtained with control $\left(277.13 \mathrm{q} \mathrm{ha}^{-1}\right)$. The lower values of growth and yield attributes were recorded under control .In general combined application of zinc and boron was found significantly superior over their alone application
\end{abstract}

Key words: Zinc, boron, cauliflower, curd yield, vegetative growth

\section{INTRODUCTION}

Cauliflower

(Brassica

oleracea

Var.botrytis L.) is an important cole crop and belongs to Brassicacea or Crucifereae family originated in Mediterranean region having chromosomes no $2 n=18$. The edible part of cauliflower is known as curd which is made from numerous divided hypertrophic branches which terminate the main stem of the plant. Cauliflower is a rich source of minerals like potassium, iron, phosphorus, magnesium, sodium, and calcium etc and plays an important role in the body's metabolism. Cauliflower is a heavy feeder crop and it respond very well to nutrients (Pawar et al.2017). The edible part i.e. curd is generally white in colour varies withyellow, creamy and white green .Cauliflower is cultivated for its attractive curd (shortened and flower Part) which is a rich source of protein and used for making vegetable, curry, soup and pickles. Zinc is an indispensable micronutrient for proper growth and development. It plays an important role in different plant metabolic process such as enzyme activity development of cell wall, respiration, photosynthesis, chlorophyll formation and other biological function. It also plays an important role for conversion of starches to sugar and its presence in plant tissue helps the plant to withstand cold temperature. Zinc is essential in the formation of auxins, which help with growth regulation and stem elongation. Boron plays a key role in a diverse range of plant functions including cell wall formation and stability, maintenance of structural and functional integrity of biological membranes, movement of sugar or energy into growing parts of plants, pollination and seed set. Adequate boron is also required for effective nitrogen fixation and nodulation in legume crops. The foliar application of boron and zinc has been reported beneficial for improving the productivity and quality of vegetable crops by Yadav et al.(2019) and Kumar et al.(2020). However, little work has been done on this aspect on cauliflower in Agra region. Therefore, present study was carried out to assess the effect of foliar application of zinc and boron on cauliflower.

\section{MATERIALS AND METHODS}

The experiment was conducted at research farm ofRaja Balwant Singh College, Bichpuri, Agra during rabi season of 2018-19. The research farm is situated at latitude of $27^{\circ} 2^{\prime}$ $\mathrm{N}$ and longitude of $77^{\circ} 2^{\prime} \mathrm{E}$ at an elevation of $163.4 \mathrm{~m}$ above the mean sea level. The Agra tract has a subtropical climate with hot dry 
summer and severs winter. Under normal climate condition the area receives about 670 $\mathrm{mm}$ annual rain fall, around $80 \%$ of which occurs from July to September. The mean annual maximum and minimum atmospheric temperature are $46^{\circ} \mathrm{C}$ and $1-2^{\circ} \mathrm{C}$, respectively. The soil of experimental plot was Gangetic alluvial with calcareous layer at the depth of about 1.5-2.0 meter. It was sandy loam in texture and slightly alkaline in reaction $(\mathrm{pH}$ 7.9). The soil had $3.5 \mathrm{~g} \mathrm{~kg}^{-1}$ organic carbon, $155 \mathrm{~kg} \mathrm{ha}^{-1}$ available nitrogen, $9.5 \mathrm{~kg} \mathrm{ha}^{-1}$ available $\mathrm{P}$ and $115 \mathrm{~kg} \mathrm{ha}^{-1}$ available $\mathrm{K}$. The DTPA $\mathrm{Zn}$ and available $B$ was 0.53 and $0.21 \mathrm{mg} \mathrm{kg}^{-1}$, respectively. The investigation was laid out in randomized block design having 9 treatments namely $\mathrm{T}_{0}$ Control, $\mathrm{T}_{1} 0.0 \% \mathrm{Zn}+0.1 \%$ Boron, $\mathrm{T}_{2}$ $0.0 \% \mathrm{Zn}+0.2 \%$ Boron, $\mathrm{T}_{3} 0.25 \% \mathrm{Zn}+0.0 \%$ Boron, $\mathrm{T}_{4}$ 0.25\% $\mathrm{Zn}+0.1 \%$ Boron, $\mathrm{T}_{5}$ 0.25\% $\mathrm{Zn}$ $+0.2 \%$ Boron, $\mathrm{T}_{6} 0.5 \% \mathrm{Zn}+0.0 \%$ Boron, $\mathrm{T}_{7}$ $0.5 \% \mathrm{Zn}+0.1 \%$ Boron and $\mathrm{T}_{8} \quad 0.5 \% \mathrm{Zn}+0.2 \%$ Boron. The seedling of cauliflower (about 35 days in age) cv. Pusa Shubhra was transplanted on16.10.2018 followed by light irrigation. The recommended dose of $\mathrm{N}, \mathrm{P}$ and $\mathrm{K}$ fertilizer (150 $\mathrm{kg} \mathrm{N}+50 \mathrm{Kg} \mathrm{P}_{2} \mathrm{O}_{5}+50 \mathrm{~kg} \mathrm{~K}_{2} \mathrm{O} \mathrm{ha}^{-1}$ ) was applied as urea, di -ammonium phosphate and muriate of potash, respectively. The sources of $\mathrm{Zn}$ and $\mathrm{B}$ were zinc sulphate and borax, respectively. Two foliar sprayings of $\mathrm{Zn}$ and boron were applied after 40 days of transplanting followed by second after 15 days of transplanting. The spacing from plant to plant was kept $50 \mathrm{~cm}$ and line to line was also $50 \mathrm{~cm}$. The observations on vegetative growth characters viz. Plant height, diameter of stem, spread of plant across the row, number of fully opened leaves, length and weight of longest leaf and yield as well as yield attributes i.e. fresh weight of leaves, curd and whole plant, diameter of curd, yield of curd, dry matter of leaves and curd were recorded at harvest. Data on different parameters were analysed statistically as suggested by Panse and Sukhatme (1995).

\section{RESULTS AND DISCUSSION}

\section{Growth parameters}

Data (Table 1) indicated that the different treatments showed significant beneficial effect on vegetative characters of cauliflower over control. The plant height progressively increased over untreated plants with the rising concentrations of $\mathrm{Zn}$ and $\mathrm{B}$. The maximum plant height of cauliflower $(44.90 \mathrm{~cm})$ and diameter of stem $(1.68 \mathrm{~cm})$ were recorded with foliar application of $0.5 \% \mathrm{Zn}+0.2 \%$ boron which were higher by 15.6 and $23.5 \%$ in plant height and diameter of stem, respectively as compared to control (Table 1).

Table 1: Effect of different treatments on vegetative growth of cauliflower

\begin{tabular}{|c|c|c|c|c|c|c|c|}
\hline Treatments & $\begin{array}{c}\text { Plant } \\
\text { height } \\
(\mathrm{cm})\end{array}$ & $\begin{array}{c}\text { Diameter } \\
\text { of stem } \\
(\mathrm{cm})\end{array}$ & $\begin{array}{c}\text { Spread of } \\
\text { plant along } \\
\text { the row }(\mathrm{cm})\end{array}$ & $\begin{array}{c}\text { Spread of plant } \\
\text { across the row } \\
(\mathrm{cm})\end{array}$ & $\begin{array}{c}\text { No. of Fully } \\
\text { opened leaves } \\
\text { per plant }\end{array}$ & $\begin{array}{c}\text { Length of } \\
\text { longest leaf } \\
(\mathrm{cm})\end{array}$ & $\begin{array}{c}\text { Width of } \\
\text { longest leaf } \\
(\mathrm{cm})\end{array}$ \\
\hline $\mathrm{T}_{0}$ & 38.81 & 1.36 & 47.87 & 46.92 & 9.14 & 32.99 & 18.10 \\
$\mathrm{~T}_{1}$ & 39.60 & 1.55 & 49.11 & 49.48 & 10.77 & 33.93 & 19.62 \\
$\mathrm{~T}_{2}$ & 41.29 & 1.42 & 48.55 & 51.16 & 11.00 & 35.63 & 19.10 \\
$\mathrm{~T}_{3}$ & 40.44 & 1.50 & 50.62 & 48.96 & 12.49 & 34.44 & 19.44 \\
$\mathrm{~T}_{4}$ & 40.37 & 1.57 & 52.59 & 53.99 & 12.38 & 36.64 & 22.22 \\
$\mathrm{~T}_{5}$ & 42.94 & 1.67 & 52.51 & 55.02 & 12.44 & 34.37 & 22.92 \\
$\mathrm{~T}_{6}$ & 42.19 & 1.52 & 50.18 & 52.26 & 11.82 & 36.15 & 20.53 \\
$\mathrm{~T}_{8}$ & 40.55 & 1.59 & 53.34 & 53.54 & 12.94 & 34.37 & 22.07 \\
$\mathrm{CD}(\mathrm{P}=0.05)$ & 44.90 & 1.68 & 53.51 & 55.25 & 12.64 & 38.90 & 24.55 \\
\hline
\end{tabular}

$T_{0}$ Control, $T_{1} 0.0 \% Z n+0.1 \% B, T_{2} 0.0 \% Z n+0.2 \% B, T_{3} 0.25 \% Z n+0.0 \% B, T_{4} 0.25 \% Z n+0.1 \% B, T_{5} 0.25 \% Z n+0.2 \%$ $B, T_{6} 0.5 \% Z n+0.0 \% B, T_{7} 0.5 \% Z n+0.1 \% B, T_{8} 0.5 \% Z n+0.2 \% B$

The maximum spread of plant along and across the row $(53.51 \mathrm{~cm}$ and $55.02 \mathrm{~cm}$ ) was measured with $\mathrm{T}_{8}(0.5 \% \mathrm{Zn}+0.2 \%$ boron). However, the increase in these parameters were statistically non significant over control. The maximum length $(38.90 \mathrm{~cm})$ and width $(24.55$ $\mathrm{cm})$ of longest leaf was measured with foliar application of $0.5 \% \mathrm{Zn}+0.2 \%$ boron and minimum with control. This increase was found to be highly significant over control. This was also due to the enhancement of cell division and growth which was caused by $\mathrm{Zn}$ and $\mathrm{B}$. This is 
conformity with the findings of Sitapara et al (2011). The maximum number of fully opened leaves per plant (12.94) was counted with foliar application of $0.5 \% \mathrm{Zn}+0.1 \%$ boron followed by $\mathrm{T}_{8}(0.5 \% \mathrm{Zn}+0.2 \%$ boron) and minimum with control. However, significantly minimum plant height $(38.81 \mathrm{~cm})$, diameter of stem $(1.36 \mathrm{~cm})$, number of leaves (9.14), length of longest leaf $(32.99 \mathrm{~cm})$ and width of longest leaf $(19.10 \mathrm{~cm})$ were recorded with control(Table 1). This may be attributed to low status of available zinc and boron in experimental soil. The higher values of growth parameter with $0.50 \% \mathrm{Zn}+0.2 \%$ Boron may be attributed to increased concentration of zinc and boron in solution which are essential for growth of cauliflower. These finding are in close proximity to the results reported by Kamal Kant et al. (2014) and Pawar et al.2017).

\section{Yield attributes and yield}

Data (Table 2 and Fig. 1) revealed that different treatments had significant beneficial effect on yield attributes and yield of cauliflower.

Table 2: Effect of different treatments on yield attributes and yields of cauliflower

\begin{tabular}{|c|c|c|c|c|c|c|c|}
\hline Treatments & $\begin{array}{c}\text { Fresh weight } \\
\text { of trimmed } \\
\text { curd }(\mathrm{kg})\end{array}$ & $\begin{array}{c}\text { Fresh } \\
\text { weight of } \\
\text { plant }(\mathrm{kg})\end{array}$ & $\begin{array}{c}\text { Diameter of } \\
\text { curd }(\mathrm{cm}) \mathrm{N}- \\
\mathrm{S}\end{array}$ & $\begin{array}{c}\text { Diameter of } \\
\text { curd }(\mathrm{cm}) \mathrm{E}-\mathrm{W}\end{array}$ & $\begin{array}{c}\text { Yield of curd } \\
\left(\mathrm{q} \text { ha }^{-1}\right.\end{array}$ & $\begin{array}{c}\text { Dry matter } \\
\text { in trimmed } \\
\text { curd }(\%)\end{array}$ & $\begin{array}{c}\text { Dry matter } \\
\text { in leaves } \\
(\%)\end{array}$ \\
\hline $\mathrm{T}_{0}$ & 0.605 & 1.28 & 11.17 & 10.73 & 277.13 & 4.26 & 5.51 \\
$\mathrm{~T}_{1}$ & 0.750 & 1.37 & 12.08 & 11.82 & 282.60 & 5.01 & 5.94 \\
$\mathrm{~T}_{2}$ & 0.783 & 1.42 & 12.47 & 11.88 & 298.20 & 5.20 & 6.15 \\
$\mathrm{~T}_{3}$ & 0.783 & 1.48 & 12.36 & 12.37 & 298.20 & 5.25 & 6.74 \\
$\mathrm{~T}_{4}$ & 0.794 & 1.54 & 12.78 & 12.59 & 302.60 & 5.05 & 5.62 \\
$\mathrm{~T}_{5}$ & 0.882 & 1.65 & 13.87 & 12.98 & 340.46 & 5.30 & 6.02 \\
$\mathrm{~T}_{6}$ & 0.761 & 1.49 & 11.95 & 11.55 & 289.40 & 5.04 & 6.14 \\
$\mathrm{~T}_{7}$ & 0.852 & 1.59 & 13.73 & 12.54 & 326.06 & 5.17 & 6.71 \\
$\mathrm{~T}(\mathrm{P}=0.05)$ & 0.888 & 1.66 & 14.01 & 13.89 & 343.46 & 5.52 & 7.46 \\
\hline
\end{tabular}

The significantly maximum weight of trimmed curd $(0.888 \mathrm{~kg})$ was recorded with foliar application of $0.5 \% \mathrm{Zn}+0.2 \%$ boron followed by $\mathrm{T}_{5}$ and $\mathrm{T}_{7}$ and minimum $(0.605 \mathrm{~kg})$ in control.
Fresh weight of whole plant was also increased due to foliar application of $\mathrm{Zn}$ and boron but the increase was not up to the level of significance.

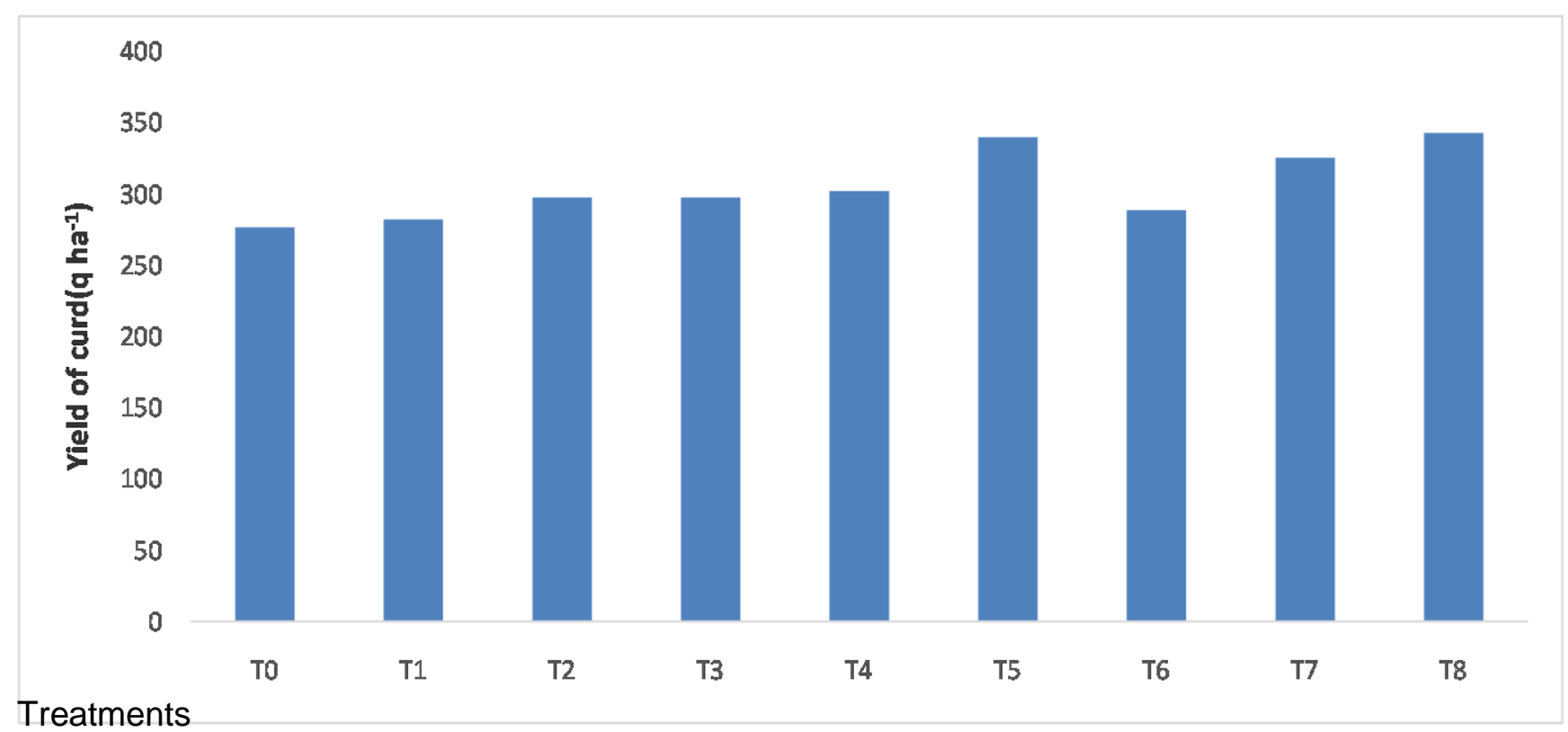

Fig. 1: Effect of different treatments on curd yield of Cauliflower 
Diameter of curd north to south and east to west increased significantly and maximum values $(14.01 \mathrm{~cm})$ and $(13.89 \mathrm{~cm})$ were measured with foliar application of $0.5 \% \mathrm{Zn}+$ $0.2 \%$ boron followed by $T_{5}$ and minimum ( 11.17 $\mathrm{cm}$ and $10.73 \mathrm{~cm}$ ) in control. Significantly maximum curd yield (343.46 q $\left.\mathrm{ha}^{-1}\right)$ was recorded with foliar application of $0.5 \% \mathrm{Zn}+$ $0.2 \%$ boron, which was 23.9 per cent higher as compared to curd yield obtained in control (277.13 q ha-1). The mean yield of curd showed significant superiority with $T_{7}, T_{5}$ and $T_{4}$ over the control in descending order. Increased yields due to $\mathrm{Zn}$ and $\mathrm{B}$ spraying may be attributed to enhanced photosynthetic activity resulting in the increased production and accumulation of carbohydrates and favourable effect on vegetative growth and curd which might have increased yield (Kumar et al. 2020). Dry matter content in trimmed curd and leaves were also

\section{RFERENCES}

Kamal Kant, Singh, K.P and Singh, V.K (2013) Comparative study of different dosesof $B$ and $\mathrm{Zn}$ on Yield and quality of cauliflower (Brassica oleracea Var Bortrytis) cv Hybrid Himani, Asian Journal of Horticulture 8(1):238-240.

Kanaujia, S.P .Ahmed,N., Chattoo, M.H., Jabeen Nayeema and Narayan, S.(2006) Effect of micro nutrient on growth and yield of cabbage (Brassica oleracia Var. Capitata L.), Applied Biological Research 8(1\&2): 0972-0979.

Kumar, A., Chauhan T.M and Parmar, A.S. (2020) Effect of foliar application of micronutrientson yield, quality and uptake nutrients in tomato (Lycopersicon esculentum). Annals of Plant and Soil Research 22(2):202-205.

Makikar, M.S, Waskar, D.P., Maind, M.M. and Bahiram, V.K. (2018) Studies on effect of micro nutrient on Growth and yield of cauliflower.Intentional Journal of Current improved due to different treatments but the effect was non significant. The highest dry matter content in trimmed curd (5.52\%) and leaves $(7.46 \%)$ was recorded with foliar application of $0.5 \% \mathrm{Zn}+0.2 \% \mathrm{~B}$ and the lowest with control. The foliar application of $\mathrm{Zn}$ and boron increased the vegetative parameters viz. plant height, number and size of leaves etc. and improved the dry matter content in curd and leaves. These findings are in consonance with the results of Makikar et al.(2018) and Kumar et al.(2020).

It may be concluded from the results that, in light textured soil deficient in available $\mathrm{Zn}$ and $\mathrm{B}$, foliar application of $\mathrm{Zn}$ and $\mathrm{B}$ resulted in higher growth and curd yield of cauliflower. Foliar application of $0.5 \% \mathrm{Zn}+0.2 \% \mathrm{~B}$ was found optimum for maintaining higher yield of cauliflower in Agra region of Uttar Pradesh.

Microbiology and Applied Science 6: 2351-2358.

Panse, V.G. and Sukhatme, P.V. (1995) Statistical Methods for Agricultural Workers. ICAR, New Delhi.

Pawar, R and Barkule, S.(2017) Study on effect of integrated nutrient management on growth and yield of of cauliflower (Brassica oleracea var.botrytis L.). Journal of Applied and Natural Science 9(1):520-525.

Sitapara, H.H. ,Vihol, N.J. Patel, M.J. and Patel J.S.(2011) Effect of growth regulators and micro-nutrient on growth and Yield of cauliflower cv. Snowball-16 Asian Journal of Horticulture 6(2):348-351.

Yadav, V., Yadav, M.S. and Prasad, F.M. (2019) Effect of gibberellic acid and boron on growth and biochemical composition of tomato (Lycopersicon esculentum) plants. Annals of Plant and Soil Research 21(2):141-144. 